\title{
A method for assessing ecological values to reconcile multiple land use needs
}

\author{
$\underline{\text { Katja M. Kangas }}^{1}$, Anne Tolvanen $^{1,2}$, Oili Tarvainen $^{1}{ }^{1}$ Ari Nikula $^{3}$, Vesa Nivala $^{3}, \underline{\text { Esa Huhta }}^{3}$ and $^{\text {Anne Jäkäläniemi }}{ }^{2}$
}

\begin{abstract}
We present a new method for ecologically sustainable land use planning within multiple land use schemes. Our aims were (1) to develop a method that can be used to locate important areas based on their ecological values; (2) to evaluate the quality, quantity, availability, and usability of existing ecological data sets; and (3) to demonstrate the use of the method in Eastern Finland, where there are requirements for the simultaneous development of nature conservation, tourism, and recreation. We compiled all available ecological data sets from the study area, complemented the missing data using habitat suitability modeling, calculated the total ecological score (TES) for each 1 ha grid cell in the study area, and finally, demonstrated the use of TES in assessing the success of nature conservation in covering ecologically valuable areas and locating ecologically sustainable areas for tourism and recreational infrastructure. The method operated quite well at the level required for regional and local scale planning. The quality, quantity, availability, and usability of existing data sets were generally high, and they could be further complemented by modeling. There are still constraints that limit the use of the method in practical land use planning. However, as increasing data become available and open access, and modeling tools improve, the usability and applicability of the method will increase.
\end{abstract}

Key Words: biodiversity; conservation; ecological value; land use planning; modeling; spatial data; tourism

\section{INTRODUCTION}

Spatial ecological data provide a starting point for estimating the ecological value of land use targets (e.g., Moilanen et al. 2005). Several techniques based on the analysis and optimization of ecological data have been specially developed for conservation planning (Sarkar et al. 2006, Lehtomäki and Moilanen 2013). Because nature conservation alone is not enough to slow down the rate of biodiversity loss, more efforts should be targeted at integrating biodiversity into broad-scale land use planning (Butchart et al. 2010). Hence, the focus of planning is shifting to approaches that consider the consequences of land use decisions within the entire landscape (Polasky et al. 2005, Willis et al. 2012, Kareksela et al. 2013).

There are at least three constraints that limit the use of spatial ecological data in land use planning: the lack of high-quality data, limited accessibility of data, and difficulties in the analysis and interpretation of the data. However, positive developments are counteracting these constraints. Data are increasingly collected by public authorities as a consequence of international agreements on nature conservation, European Union (EU) directives, and national legislation, which set frameworks and provide information for evaluating the value of biodiversity targets and ecosystem services in the planning process. The accessibility of data sets is being facilitated in the EU by, for example, the INSPIRE directive (INSPIRE 2007) and the recent trend toward a free and open access data policy (e.g., INSPIRE 2007, Woodcock et al. 2008, Wulder et al. 2012, Turner et al. 2015). Although the analysis of data still requires specific expertise, the outcome can be presented as maps, which are more easily understandable and make the decision-making process transparent to the public.

As a result of the increasing amount and accessibility of data, the mapping of biodiversity and other ecosystem services such as recreational value and commercial forestry has been carried out over large spatial scales, such as the European level (Maes et al. 2011, 2012). However, free and open access data sets such as
CORINE2000 cannot provide detailed spatial information, for example, on important habitats and species (e.g., Vihervaara et al. 2012). The national- and continent-level mapping of biodiversity and ecosystem services inevitably remains at a general level. Because the land use planning is applied mainly at regional and local levels, the assessment of ecological values and ecosystem services should be based on data containing more precise information on habitats and species (Vihervaara et al. 2012). Specific information is increasingly collected by nonpublic authorities, but the use of the data is still restricted to the actors' own purposes or the land area administered directly by the respective actor. In respect to regional-level planning, several actors and landowners are usually involved, which calls for the joint use of multiple data sets.

The interoperability of multiple data sets from multiple actors and stakeholders has rarely been evaluated and assessed (e.g., Theobald and Hobbs 2002, Vihervaara et al. 2012, 2015). The spatial overlay of existing data sets may reveal potential synergies and conflicts between land uses, which is important for the coordination and reconciliation of land uses. This paper presents a new approach to combining and testing the interoperability of spatial ecological data sets to promote ecologically sustainable land use planning within multiple land use schemes. The study had three main objectives: First, we developed a method that can be used to locate important areas based on their ecological values. Second, we evaluated the quality, quantity, availability, and usability of the existing ecological data sets. Third, we demonstrated the use of our method in North-Eastern Finland, where there are simultaneous needs for the development of nature conservation, tourism, and recreation. We compiled all available data sets from the area, complemented the missing data using habitat suitability modeling, calculated the total ecological score (TES) of the study area, and finally, demonstrated the use of TES in assessing the success of nature conservation in covering ecologically valuable areas and locating ecologically sustainable areas for tourism and building infrastructure for recreation.

\footnotetext{
${ }^{1}$ Natural Resources Institute Finland, Oulu, ${ }^{2}$ Department of Ecology, University of Oulu, ${ }^{3}$ Natural Resources Institute Finland, Rovaniemi
} 


\section{MATERIAL AND METHODS}

\section{The context and location of the study}

Tourism and recreation are considered important cultural ecosystem services that may generate support for nature conservation (Millennium Ecosystem Assessment 2005, Balmford et al. 2009, 2015, Naidoo et al. 2011) and ecological restoration. Nevertheless, the growing tourism industry requires more space for various activities and causes environmental degradation (e.g., Cole and Landres 1996, Ballantyne and Pickering 2013). The initial construction of tourism infrastructure has the most profound ecological impacts (e.g., Wipf et al. 2005, Kangas et al. 2009, Tolvanen and Kangas 2016). For example, in Eastern and Northern Finland, tourism targeted at ski resorts and nature conservation areas has become an increasingly important industry, while the role of traditional livelihoods such as forestry and agriculture has diminished (Saarinen 2003, 2005). In some areas, the overlapping needs of nature conservation, tourism, and forestry have led to conflicts (Puhakka 2007, Rytteri and Puhakka 2012), which challenges the local authorities to reconcile land uses.

We demonstrated our method in the Kainuu region of NorthEastern Finland (Fig. 1). This area is one of the tourism and recreational development centers in the region, and it comprises two ski resorts and smaller recreational areas. Several nature conservation areas (established by law or decree), nature conservation program areas (allocated for nature conservation but not yet established as protected areas by law or decree), and a strict nature reserve are located in the area to protect threatened and rare species and habitats. Apart from these protected areas, forests within the study area are subject to commercial use.

Fig. 1. Location of the study area, the nature conservation areas, and ski resorts therein.

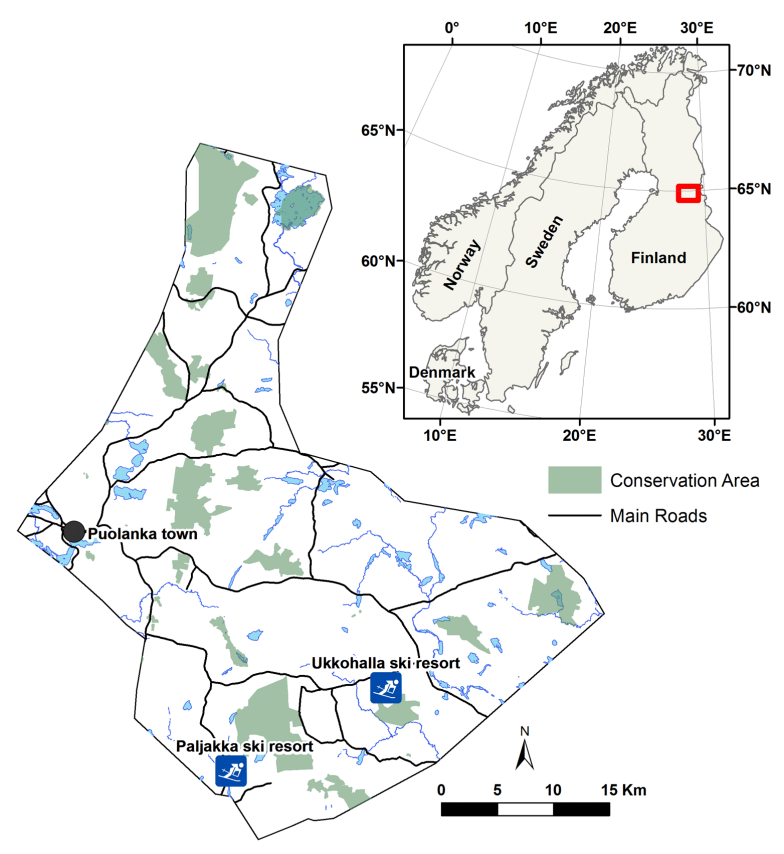

\section{Used data sets}

To locate ecologically valuable habitats and species, we gathered all available ecological data from several organizations and actors in Finland (Table 1). Data on nature conservation areas (established by law or decree) and nature conservation program areas (allocated for nature conservation but not yet established as protected areas by law or decree) were derived from the OIVA spatial web service for experts and administered by the environmental agencies. Both the established nature conservation areas and nature conservation program areas are referred to as nature conservation areas hereafter. Data on forest characteristics, habitats, and habitat types protected under the Forest and the Nature Conservation Acts in state-owned and privately owned land were derived from the databases of Metsähallitus (SutiGIS) and the Finnish Forest Centre, respectively. The data are based on both field and aerial photo inventories. Because the state-owned and privately owned data did not cover the whole study area, additional information on regional forest resources was derived from the Multi-Source National Forest Inventory (MS-NFI) database, which is based on remote sensing and field inventories, and is administered by the Natural Resources Institute Finland (Tomppo et al. 2008).

Data on the occurrence of threatened species in Finland (Rassi et al. 2010) and EU habitat and bird directives' species (Directive 92/43/EEC, Directive 2009/147/EC, respectively) were derived from the HERTTA data set administered by Finland's environmental institute (Table 1). Spatial data on threatened and old-growth forest bird species were derived from the TIIRA database updated by the Kainuu regional ornithological society and maintained by the BirdLife organization in Finland. TIIRA contains observations reported by voluntary birdwatchers. With regard to HERTTA and TIIRA, we only used species observations for which locations had been reported with the accuracy of at least one hectare. Bird data were also derived from field surveys conducted by Metsähallitus (transect length 73.65 from 2002-2007), by the Finnish Museum of Natural History (12 $\mathrm{km}$ in 2011), and in this study (79.6 km in 2012). The data were collected using the Finnish line transect method (Järvinen and Väisänen 1975), in which a prescribed route is slowly $(1 \mathrm{~km} /$ hour $^{-1}$ ) walked and all birds seen or heard are tallied. The data on bird species and their numbers recorded within the main 50$\mathrm{m}$ wide survey belt were used for this study. Bird data were transformed to a GIS database using ESRI ArcGIS for Desktop software version 10.1 .

\section{Design of ecological classification}

For the assessment of ecological values, the study area of 1411.5 $\mathrm{km}^{2}$ was divided into a $100 \mathrm{~m}$ x $100 \mathrm{~m}$ grid that contained 145,364 cells. The ecological value was assessed for four separate data layers in three phases. The four data layers were (1) areas with restricted use because of their conservation value (layer RESTRICTED), (2) endangered and rare habitats (HABITAT), (3) endangered and rare species (SPECIES), and (4) habitats suitable for characteristic species of natural landscapes based on habitat suitability modeling (MODELING). First, the variables in each data layer were given points based on their conservation and biodiversity status (Table 1). Second, the layer score was assessed as the most valuable variable in each cell in each data layer (Fig. 2). Third, the TES was calculated for each cell as the sum of the four layer scores (Fig. 2). TES denotes the ecological value of the cell. 
Table 1. Variables describing the biodiversity and conservation status of the study area in each data layer, points of each variable, and the data source. Restrictions on the data use are shown in the footnotes.

\begin{tabular}{|c|c|c|}
\hline Variables & Points & Data source \\
\hline \multicolumn{3}{|l|}{ Layer: RESTRICTED } \\
\hline \multicolumn{3}{|l|}{ Large areas $>20 \mathrm{~km}^{2}$} \\
\hline Strict nature reserve & 810 & Environmental administration (OIVA) \\
\hline Mire conservation program & 270 & Environmental administration (OIVA) \\
\hline \multicolumn{3}{|l|}{ Small areas $<20 \mathrm{~km}^{2}$} \\
\hline Mire conservation program, $<5 \%$ ditched & 90 & Environmental administration (OIVA) \\
\hline Old-growth forest conservation program & 90 & Environmental administration (OIVA) \\
\hline Shore conservation program & 90 & Environmental administration (OIVA) \\
\hline Conservation forests & 90 & Metsähallitus (SutiGIS) $^{\dagger}$ \\
\hline Special conservation areas & 90 & Environmental administration (OIVA) \\
\hline Herb-rich forest conservation program & 90 & Environmental administration (OIVA) \\
\hline Protected areas in privately owned lands, temporary preserves & 90 & Environmental administration, (OIVA) \\
\hline Forest Act habitats & 90 & Metsähallitus (SutiGIS), Finnish Forest Centre ${ }^{\dagger}$ \\
\hline Nature Conservation Act habitats & 90 & Metsähallitus (SutiGIS), Finnish Forest Centre \\
\hline Waterfowl habitats conservation program & 90 & Environmental administration (OIVA) \\
\hline Traditional rural biotopes & 90 & $\begin{array}{l}\text { Centre for Economic Development, Transport and the } \\
\text { Environment (Kainuu ely) }\end{array}$ \\
\hline Habitats for species of special concern & 90 & Environmental administration (OIVA) \\
\hline Other small areas with restricted use (e.g., gene reserves) & 90 & Metsähallitus (SutiGIS) \\
\hline Mire conservation program, $>5 \%$ ditched & 30 & Environmental administration (OIVA) \\
\hline \multicolumn{3}{|l|}{ Other areas } \\
\hline Other protected areas & 30 & Metsähallitus (SutiGIS) \\
\hline Other valuable habitats & 30 & Finnish Forest Centre \\
\hline Important habitats for game & 30 & Metsähallitus (SutiGIS), Finnish Forest Centre \\
\hline Esker conservation program & 10 & Environmental administration (OIVA) \\
\hline Prioritized cliff habitats & 10 & Environmental administration (OIVA) \\
\hline Prioritized esker habitats & 10 & Metsähallitus (SutiGIS) \\
\hline Prioritized groundwater habitats & 10 & Metsähallitus (SutiGIS) \\
\hline \multicolumn{3}{|l|}{ Layer: HABITATS } \\
\hline Critically endangered habitats (CR) & 810 & Metsähallitus (SutiGIS) \\
\hline Endangered habitats (EN) & 270 & Metsähallitus (SutiGIS) \\
\hline Vulnerable habitats (VU) & 90 & Metsähallitus (SutiGIS) \\
\hline Old-growth forests (several habitat types) & 90 & Metsähallitus (SutiGIS), Finnish Forest Centre \\
\hline Near threatened habitats (NT) & 30 & Metsähallitus (SutiGIS) \\
\hline Rich fens, spruce mires and herb-rich forests & 10 & Metsähallitus (SutiGIS), Finnish Forest Centre \\
\hline \multicolumn{3}{|l|}{ Layer: SPECIES } \\
\hline Critically endangered species (CR) & 810 & Environmental administration $(\text { Hertta })^{\dagger}$, TIIRA $^{\dagger}$ \\
\hline Endangered species (EN) & 270 & Environmental administration (Hertta), TIIRA \\
\hline Vulnerable species (VU) & 90 & Environmental administration (Hertta), TIIRA \\
\hline Near threatened species (NT) & 30 & Environmental administration (Hertta), TIIRA \\
\hline $\begin{array}{l}\text { Locally threatened species, EU habitat and bird directive species, } \\
\text { rare species, old-growth forest species }\end{array}$ & 10 & Environmental administration (Hertta), TIIRA \\
\hline \multicolumn{3}{|l|}{ Layer: MODELING } \\
\hline Suitable habitats for Pteromys volans & 10 & \\
\hline Suitable habitats for Amylocystis lapponicus & 10 & \\
\hline Suitable habitats for old-growth forest bird & 10 & \\
\hline
\end{tabular}

Data for official and/or research purpose only.

${ }^{\ddagger}$ Free access, but registration required.

The lowest value (apart from zero) for variables presenting conservation and biodiversity status was set to 10 points, and the following levels were set to threefold the previous ones, i.e. 30,90 , 270 , and 810 points. The threefold increase was used to emphasize the ecological importance of the most valuable variables, which have the greatest impact on land use decisions. Consequently, a cell can achieve a high TES because of a very high layer score in one data layer (for example, a strict nature reserve of 810 points; Table 1, Fig. 2), whereas other cells need to attain the second highest score from at least three data layers to achieve the same TES (for example, large conservation areas, endangered habitat, and an endangered species, $3 \times 270$ scores). Using a smaller multiplier, e.g., two, would have resulted in TES equalling 160 in the cell with the strict nature reserve, which is the most valuable piece of nature in the area. A cell with only an endangered habitat and an endangered species would also achieve the same TES of 160 , which would underestimate the importance of the strict nature reserve in land use decisions. A larger multiplier would have emphasized the ecological importance of the most valuable variables even further, which was regarded as being unnecessary. The scoring was carried out in the workshops of experienced biodiversity specialists, comprising researchers, conservation 
biologist, and practitioners principally in the Natural Resources Institute Finland and Metsähallitus. The scoring method has been used successfully in tourism planning in the Kainuu region (Tolvanen et al. 2014) and as a modified version in the city planning of Oulu in Northern Finland (Kangas et al. 2013). To estimate the importance and usability of the used data sets and data layers, we explored their coverage and relative contribution to TES. The correlations between the layers as well as the TES were explored using the Spearman rank correlation.

Fig. 2. The total ecological score (TES) was calculated for each 1-ha cell in the study area. Layer scores were assessed as the most valuable variable in each cell in each data layer: (1) RESTRICTED, (2) HABITAT, (3) SPECIES, and (4) MODELING. The TES is the sum of the four layer scores.
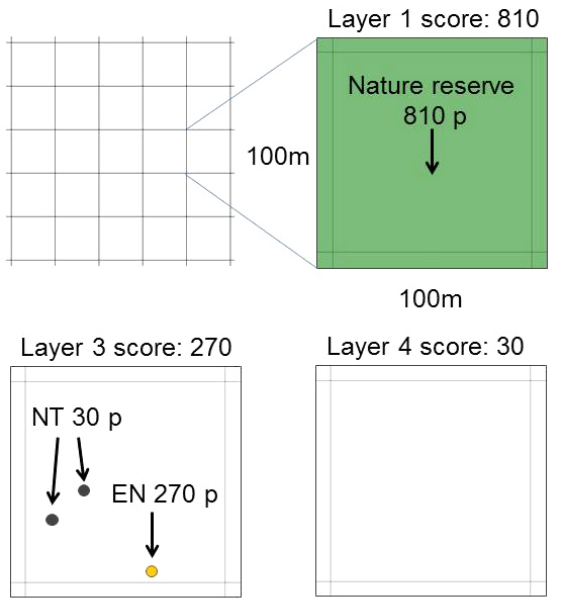

$100 m$

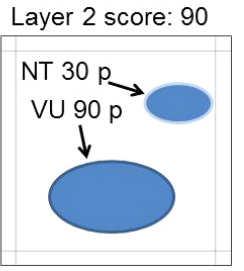

TES: 1200

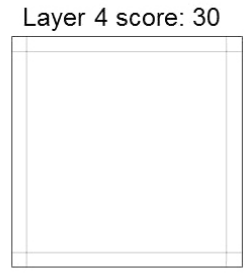

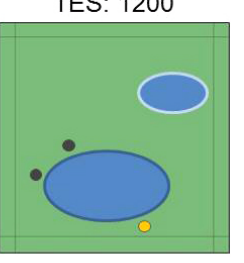

The description and valuing of variables within the four data layers

The RESTRICTED layer included all areas with restricted or limited land use, i.e., where, for example, forestry operations are not permitted or they have to be conducted without changing the environments' characteristic features. Information on the size of the area, amount and type of human impact, and elapsed time since the impact were used in the valuing of the variables as points. The restricted areas were categorized into three main types: large $\left(>20 \mathrm{~km}^{2}\right)$ conservation areas, small $\left(<20 \mathrm{~km}^{2}\right)$ conservation areas or otherwise ecologically valuable areas, and other areas with limited land use (Table 1). The large restricted areas were given the most points, because they generally contain several habitat types and species and their ecosystem dynamics, such as vegetation succession, forest disturbance dynamics, and hydrology, are quite natural. Strict nature reserves were given the maximum value of 810 points because of the highest possible nature conservation status such an area can have in Finland. Large conservation areas with lower restriction status were given 270 points. In smaller restricted areas, both the habitat and species richness are lower and the surrounding land use, such as forestry drainage, may have negative impacts on their hydrology and biodiversity. Hence, they were given 90 points. Mire conservation areas with a high amount of drainage $(>5 \%)$ were given only 30 points, because they may need specific activities to restore their hydrology and biodiversity (Laine et al. 2011).
The HABITAT layer included habitat types that are considered threatened according to the first assessment of the threatened habitat types in Finland (Raunio et al. 2008). The assessment is based on two main criteria: the change in the quantity and quality of the habitat types from the 1950s and the possible earlier changes and predicted future trends (Raunio et al. 2008). Because the assessment is descriptive and no extensive data sets are available, we located the threatened habitat types manually on state-owned land based on the habitat characteristics information in the SutiGIS database owned by Metsähallitus. Based on the assessment, critically endangered habitats were given the highest value of 810 points, and endangered, vulnerable, and nearthreatened habitats were assigned 270, 90 and 30 points, respectively (Table 1). To also consider key habitats on private land, the locations of old-growth forests, rich fens, spruce mires, and herb-rich forests were derived from the data set of the Finnish Forest Centre. Old-growth forests were given 90 points, because most old-growth forest types belong to the vulnerable category at least, according to Raunio et al. (2008).

The SPECIES layer included nationally threatened vascular plants, polypores, lichens, mosses, and the flying squirrel (Ptyeromys volans) based on the conservation assessment by Rassi et al. (2010). The species are classified using the International Union for Conservation of Nature Red List Categories. As in habitats, critically endangered species were given the highest value of 810 points (Table 1). We also included species listed in the EU habitat and bird directives (Directive 92/43/EEC, Directive 2009/147/EC, respectively), bird species typical for old-growth forests (Väisänen et al. 1998, Rajasärkkä 2004), and regionally threatened or other rare species that have previously been considered regionally threatened. These species were given 10 points.

The MODELING layer was based on habitat suitability modeling. The modeling approach was used because most of the species' data are dispersed rather than being systematic observations, and the data among landowners were unbalanced, being covered more in state-owned than private land. Models were constructed for species that characterize valuable old-growth spruce forests typical in the study area: flying squirrel, bracket fungus (Amolocystis lapponica), and the group of old-growth forest birds: Northern Goshawk (Accipiter gentilis), Golden Eagle (Aquila chrysaetos), Western Capercaillie (Tetrao urogallus), Tengmalm's Owl (Aegolius funereus), Grey-headed Woodpecker (Picus canus), Black Woodpecker (Dryocopus martius), Threetoed Woodpecker (Picoides tridactylus), Bohemian Waxwing (Bombycilla garrulus), Winter Wren (Troglodytes troglodytes), Orange-flanked Bush Robin (Tarsiger cyanurus), Mistle Thrush (Turdus viscivorus), Greenish Warbler (Phylloscopus trochiloides), Red-breasted Flycatcher (Ficedula parva), Crested Tit (Lophophanes cristatus), Eurasian Tree-creeper (Certhia familiaris), and Siberian Jay (Perisoreus infaustus).

For the modeling, we selected observations of species with at least 100-m accuracy recorded after 2000. Because of possible landscape changes in the areas of older observations, we also required all observations to have been made in the forest-covered area, which were checked against the latest land use and forest data from the National Forest Inventory (MS-NFI data). A total of 591 observations, hereafter referred to as observation points, of old-growth forest birds, 108 observation points of flying 
Table 2. Land use and forest classification used in the habitat suitability modeling and the criteria for land use classes derived from multisource National Forest Inventory Data (Tomppo et al 2008).

\begin{tabular}{|c|c|c|}
\hline Land use and forest classes & $\begin{array}{l}\text { Growing stock volume, } \mathrm{m}^{3} \\
\mathrm{ha}^{-1}\end{array}$ & $\begin{array}{l}\text { Criteria for dominant tree species, proportion of tree } \\
\text { species of growing stock }(\%) \text {, ditching }\end{array}$ \\
\hline \multicolumn{3}{|l|}{ Old-growth forests, nonditched } \\
\hline Deciduous forests & $>120$ & Deciduous trees $>60 \%$ \\
\hline Mixed deciduous forests & $>120$ & None of the species $>60 \%$, deciduous trees $20 \%-60 \%$ \\
\hline Mixed coniferous forests & $>120$ & None of the tree species $>60 \%$, deciduous trees $<20 \%$ \\
\hline Scots pine-dominated forests & $>120$ & Pine $>60 \%$ \\
\hline Spruce-dominated forests & $>120$ & Spruce $>60 \%$ \\
\hline \multicolumn{3}{|l|}{ Young and advanced thinning forests, ditched and nonditched } \\
\hline Mixed deciduous forests & $91-120$ & None of the tree species $>60 \%$, deciduous trees $20 \%-60 \%$ \\
\hline Mixed coniferous forests & $91-120$ & None of the tree species $>60 \%$, deciduous trees $<20 \%$ \\
\hline Scots pine-dominated forests & $91-120$ & Pine $>60 \%$ \\
\hline Spruce-dominated forests & $91-120$ & Pine $>60 \%$ \\
\hline Deciduous forests & $91-120$ & Deciduous trees $>60 \%$ \\
\hline \multicolumn{3}{|l|}{ Young thinning forests, ditched and nonditched } \\
\hline Deciduous forests & $41-90$ & Deciduous trees $>60 \%$ \\
\hline Mixed deciduous forests & $41-90$ & None of the tree species $>60 \%$, deciduous trees $20 \%-60 \%$ \\
\hline Mixed coniferous forests & $41-90$ & None of the tree species $>60 \%$, deciduous trees $<20 \%$ \\
\hline Scots pine-dominated forests & $41-90$ & Pine $>60 \%$ \\
\hline Spruce-dominated forests & $41-90$ & Pine $>60 \%$ \\
\hline \multicolumn{3}{|l|}{ Other } \\
\hline Plantations & $5-40$ & No criteria for tree species, ditched and nonditched \\
\hline Fully stocked ditched forests & $>120$ & Ditched \\
\hline $\begin{array}{l}\text { Treeless areas, agricultural land, built-up areas, inhabited } \\
\text { areas, roads, waters, peat production areas }\end{array}$ & $<5$ & - \\
\hline
\end{tabular}

squirrel, and 80 observation points of bracket fungus were used in the modeling. For the purpose of modeling, we created as many random points for the study area as there were observations points for each species or species group. We used MS-NFI data (25 m x $25 \mathrm{~m}$ resolution) as land use and land cover data (Tomppo et al. 2008). We classified the data into 18 land use and forest classes (Table 2). For each land use and forest class, we calculated the proportions of those classes (percentage) out of the total area around each observation point and a random point using Fragstats (McGarigal and Marks 1995). We used a radius of 250 $\mathrm{m}$ for bracket fungus and $500 \mathrm{~m}$ for flying squirrel and bird species.

Because our response variable was binary (observation pointrandom point) we used logistic regression (Hosmer and Lemeshow 2000). Modeling was made with the SAS LOGISTIC procedure (SAS Institute 2004) by using the binary distribution and logit link and stepwise method for variable selection. Final model variables with estimates were selected by using Akaike information criteria and model performance measures (Burnham and Anderson 2002). By using 50\% probability, the model correctly predicted $88.7 \%$ of all points concerning whether the observation belonged to the old-growth forest bird observation point or the random point. When only species observation points were considered, the model predicted bird observations correctly with an accuracy of $84.8 \%$. For the flying squirrel, the respective percentages were $80.6 \%$ and $74.1 \%$, and for bracket fungus they were $86.9 \%$ and $85 \%$.
After obtaining the final models, we placed two regular grids of points with the distances of $500 \mathrm{~m}$ and $250 \mathrm{~m}$ over the study area and calculated the respective landscape indices as in the models (Table 2) for every grid point and by using the same radii as for observation points and random points. By placing the landscape indices from each grid point in the models, we then calculated the probability of bird habitats, flying squirrel habitats, and bracket fungus habitats for each grid point. Probabilities were finally interpolated to $100 \mathrm{~m} \times 100 \mathrm{~m}$ grid cells by using the Natural Neighbor method in ArcMap 10.1 (ESRI 2011).

In the MODELING layer, we gave 10 points to each cell if any of the models showed the probability of a suitable habitat being $>0.5$ for flying squirrel, bracket fungus, or the bird species group (Table 1). If the habitat was considered suitable for two species, it was given 30 points, and if suitable for all modeled species it was given 90 points. Because the modeling layer was based on estimated values, the assigned points were lower than those assigned in the other layers.

\section{Demonstration of the method}

We demonstrated the method in a practical land use planning case in the study area. First, we assessed the success of nature conservation in covering ecologically valuable areas. It should be remembered that the conservation areas are not the same as the whole RESTRICTED layer. The latter also includes areas, where, for example, some forestry operations are possible, as long as they do not change the characteristic features of the area. We calculated the number and proportion of cells with layer scores 
Table 3. Number of 1-ha cells in the score classes for each layer. The relative proportions (\%) of each score class from all cells (145,364) are presented in parentheses. Score classes: 0, 10, 30, 90, 270, and 810. No. of cells $=$ number of cells with score $>0$. Layer score presents the sum of scores of all cells at the layer in question.

\begin{tabular}{|c|c|c|c|c|c|c|c|c|}
\hline Layer & 0 & 10 & 30 & 90 & 270 & 810 & No. of cells & Layer score sum \\
\hline RESTRICTED & $\begin{array}{c}110,122 \\
(75.8)\end{array}$ & $\begin{array}{c}1335 \\
(0.92)\end{array}$ & $\begin{array}{c}7295 \\
(5.02)\end{array}$ & $\begin{array}{l}19,890 \\
(13.68)\end{array}$ & $\begin{array}{l}3580 \\
(2.46)\end{array}$ & $\begin{array}{l}3142 \\
(2.16)\end{array}$ & $\begin{array}{c}35,242 \\
(24.2)\end{array}$ & $5,533,920$ \\
\hline HABITAT & $\begin{array}{c}104,093^{\dagger} \\
(71.6)\end{array}$ & $\begin{array}{l}15,487 \\
(10.65)\end{array}$ & $\begin{array}{c}5634 \\
(3.88)\end{array}$ & $\begin{array}{l}13,327 \\
(9.17)\end{array}$ & $\begin{array}{l}4598 \\
(3.16)\end{array}$ & $\begin{array}{l}2225 \\
(1.53)\end{array}$ & $\begin{array}{l}41,271 \\
(28.4)\end{array}$ & $4,567,030$ \\
\hline SPECIES & $\begin{array}{c}143,530 \\
(98.7)\end{array}$ & $\begin{array}{c}320 \\
(0.22)\end{array}$ & $\begin{array}{c}632 \\
(0.43)\end{array}$ & $\begin{array}{c}757 \\
(0.52)\end{array}$ & $\begin{array}{c}117 \\
(0.08)\end{array}$ & $\begin{array}{c}8 \\
(0.01)\end{array}$ & $\begin{array}{l}1834 \\
(1.3)\end{array}$ & 128,360 \\
\hline MODELING & $\begin{array}{l}97,962 \\
(67.4)\end{array}$ & $\begin{array}{l}24,295 \\
(16.71)\end{array}$ & $\begin{array}{c}9838 \\
(6.77)\end{array}$ & $\begin{array}{l}13,269 \\
(9.13)\end{array}$ & & & $\begin{array}{c}47,402 \\
(32.6)\end{array}$ & $1,732,300$ \\
\hline
\end{tabular}

Layers: RESTRICTED = conservation areas or other areas with restricted use, HABITAT $=$ endangered and rare habitats, SPECIES $=$ endangered and rare species, and MODELING = habitat suitability modeling.

${ }^{\dagger}$ Missing data in 24346 cells.

of $>0$ within and outside the conservation areas separately for each data layer.

Second, we used TES to locate ecologically sustainable areas for tourism and recreational infrastructure. We indicated four intensity levels based on TES and the information on tourism impacts on the biodiversity in related ecosystems (Tolvanen and Kangas 2016). The cells with TES $=0$ were regarded as being suitable for the heavy construction of infrastructure, e.g., hotels, cabins, and parking lots, because of their low ecological values. The cells with TES 10-80 were regarded as suitable for intermediate-level infrastructure, e.g., wilderness huts, campfire sites, and lean-to shelters. The cells with TES 90-800 were regarded as suitable for light infrastructure, e.g., hiking routes and skiing tracks. These areas contain small or large restricted areas and/or threatened habitats and species that are regarded as being vulnerable or endangered. The cells with TES $\geq 810$ were considered unsuitable for tourism and recreational infrastructure. These areas contained strict nature reserves and/or critically endangered habitats or species, indicating that their ecological values might be compromised even by low levels of tourism and recreational activities.

\section{RESULTS}

\section{Data set evaluation and TES}

The most comprehensive spatial information was obtained from the SutiGIS data set and the Finnish Forest Centre data set, covering $52.8 \%$ and $36.9 \%$ of the 145,364 cells in the study area, respectively. These data sets include information that was used in the RESTRICTED and the HABITAT layers. The proportion of cells without data from either of these data sets was $16.7 \%$, and they were located on private land. This reduced the accuracy of the HABITAT layer, which only contained data from SutiGIS and the Finnish Forest Centre. The other data layers included data that covered the whole study area, although the species data used in the SPECIES and MODELING layers were derived from databases that are not based on systematic inventories in the study area.

In total, $71,741(49.4 \%)$ of the cells had TES $>0$ and $24 \%$ of the cells with TES $=0$ were located in areas lacking the most comprehensive data by SutiGIS and the Finnish Forest Centre. None of the cells achieved the potential maximum TES of 2520, the highest TES being 1980. The number of cells obtaining layer scores of $>0$ was highest at the MODELING layer and next highest at the HABITAT layer (Table 2, Fig. 3). Without the MODELING layer, the number of cells with TES $>0$ was 53,116 (36.5\%), TES ranging from 10 to 1890 . Thus, the inclusion of the MODELING layer increased the number of cells achieving TES by 18,625 cells $(12.8 \%)$, of which $5487(29.4 \%)$ were located in the areas lacking the most comprehensive data.

The layer score sum (i.e., the sum of layer scores of all cells at a given layer) was highest at the RESTRICTED layer, which comprised almost half $(46.3 \%)$ of the TES of the study area based on all four layers (Table 3 ). In this layer, most cells having a layer score of $>0$ had 90 scores. The HABITAT layer had the second highest layer score sum and comprised $38.2 \%$ of the TES of the study area. In this layer, the most cells having layer scores of $>0$ had 10 scores. The MODELING layer comprised $14.5 \%$ of the TES of the study area, and the SPECIES layer 1.1\% (Table 3).

There was a significant positive correlation between the layer scores of each data layer and TES, indicating that the layers had high scores for the same cells (Table 4). The TES correlated strongest with the RESTRICTED layer. Also, the HABITAT and MODELING layers had strong correlations with TES. The RESTRICTED and HABITAT layers also had a relatively strong correlation with each other. The SPECIES layer had the weakest correlation with the other data layers and TES.

Table 4. Correlation matrix between the layer scores and the total ecological score (TES) based on all layers.

\begin{tabular}{|c|c|c|c|c|}
\hline & $\begin{array}{c}\text { RESTRIC- } \\
\text { TED }\end{array}$ & HABITAT & SPECIES & MODELING \\
\hline $\begin{array}{l}\text { RESTR- } \\
\text { ICTED }\end{array}$ & & & & \\
\hline $\begin{array}{l}\text { HABIT- } \\
\text { AT }\end{array}$ & $0.56 * *$ & & & \\
\hline SPECIES & $0.14 * *$ & $0.13 * *$ & & \\
\hline $\begin{array}{l}\text { MODE- } \\
\text { LING }\end{array}$ & $0.45 * *$ & $0.31 * *$ & $0.14 * *$ & \\
\hline TES & $0.8 * *$ & $0.76^{* *}$ & $0.17 * *$ & $0.6^{* *}$ \\
\hline
\end{tabular}


Fig. 3. Layer scores of (a) RESTRICTED, (b) HABITAT, (c) SPECIES, and (d) MODELING layers, and (e) the total ecological score (TES) when all layers are aggregated.

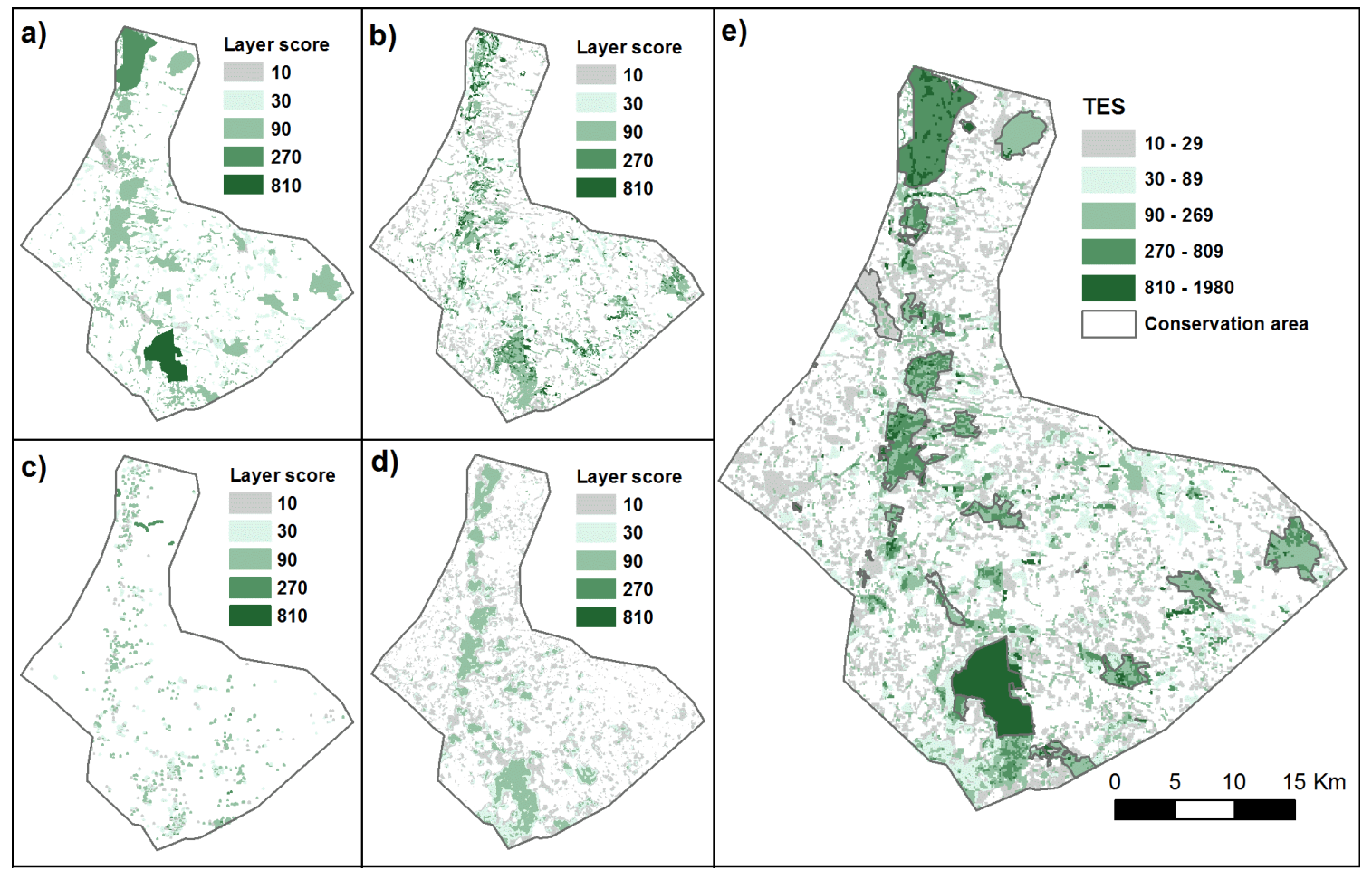

\section{The success of nature conservation}

There were more than two times as many cells achieving TES > 0 outside conservation areas than within conservation areas (Figs. 3 and 4). Of the cells with TES $>0$ outside the conservation areas, approximately half had TES between 10 and 29, whereas TES ranged principally between 90 and 809 within the conservation areas. Altogether, $5186(3.6 \%)$ cells in the study area received TES $\geq 810$ (highest TES 1980), most of them being within the conservation areas (Figs. 3 and 4). Almost 15\% of cells with TES $\geq 810$ were outside conservation areas, the highest TES being 1080 (Figs. 3 and 4). These small areas, containing critically endangered habitats or species, were generally a part of the larger area with a high TES and located close to the conservation areas (Fig. 3).

When the four data layers were evaluated separately, only in the RESTRICTED layer were there more cells within the conservation areas achieving layer scores of $>0$ compared to cells outside the conservation areas (Fig. 3). Regarding the HABITAT and MODELING layers, there were approximately two times as many cells with a layer score of $>0$ outside the conservation areas than inside (Fig. 3). However, more than half of these cells belonged to the lowest score class 10. Surprisingly, in the SPECIES layer there were more cells with a layer score of 810 outside than inside the conservation areas.

\section{Levels of ecologically sustainable tourism and recreation}

According to the used intensity levels, $50.6 \%$ of the cells were suitable for the construction of all kinds of tourism infrastructure, $26.4 \%$ for intermediate infrastructure, $19.4 \%$ for light infrastructure, and $3.6 \%$ were unsuitable for tourism or recreation
(Fig. 5). As expected, the cells unsuitable for tourism or suitable only for light infrastructure were often located within conservation areas (Fig. 5).

\section{DISCUSSION}

We developed a new method for ecologically sustainable land use planning that uses multiple data sets. We also showed that the quality, quantity, availability, and usability of existing ecological data were generally high and could be further complemented by modeling. The method operated quite well in the demonstration planning case that had simultaneous needs for nature conservation, tourism, and recreational development. The results are promising considering the developed method, the joint use of multiple data sets, the transferability of the method, and its practical implications. Nevertheless, there are still constraints and open questions, which are discussed below.

\section{Method and data evaluation}

The assessment of the ecological value by experts was unavoidably subjective to some degree. The subjectivity in choosing the parameters behind the modeling or assigning points is, however, not a problem as long as the process is transparent and the experts use their best judgement in valuation (Krueger et al. 2012, Laniak et al. 2013). The framework for the scoring in this study was derived from international and national assessments, and the current legislative status of the areas. Nevertheless, the method can be transferred to other regions because it allows for flexible adjustment of the scoring and weighing of layers to local conditions, available data sets, and stakeholder needs. In our case, the RESTRICTED, HABITAT, and SPECIES layers were 
Fig. 4. Number of cells with total ecological score (TES) $>0$ in the score classes $(10,30,90,270,810)$ in each layer within and outside conservation areas (CAs). (a) RESTRICTED layer, (b) HABITAT layer, (c) MODELING layer, (d) SPECIES layer, and (e) TES.

$$
\text { a) }
$$

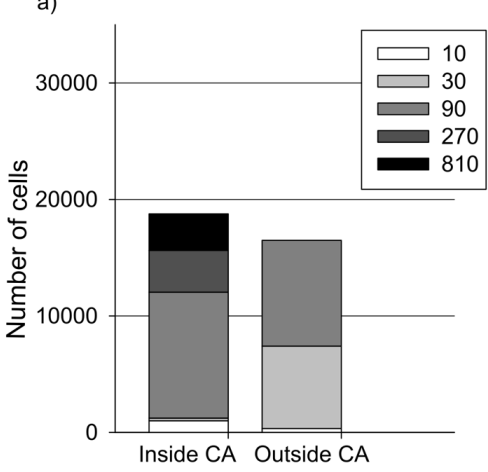

d)

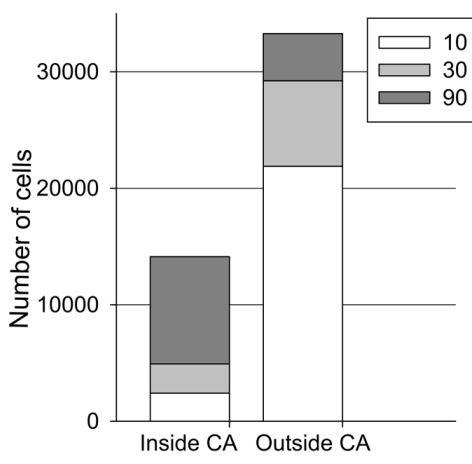

b)

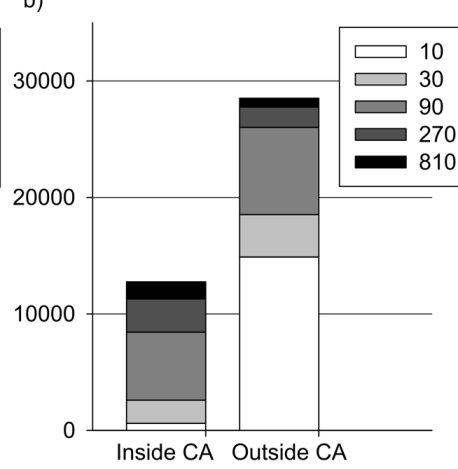

e)

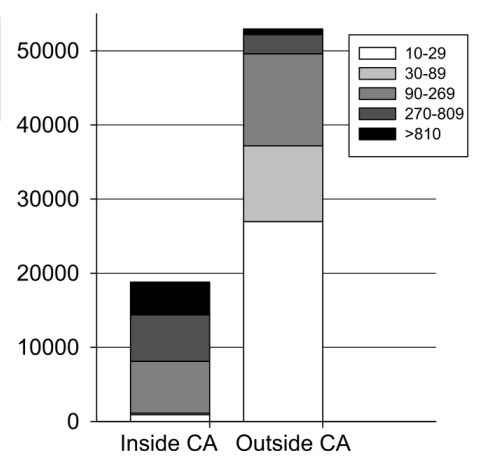

c)

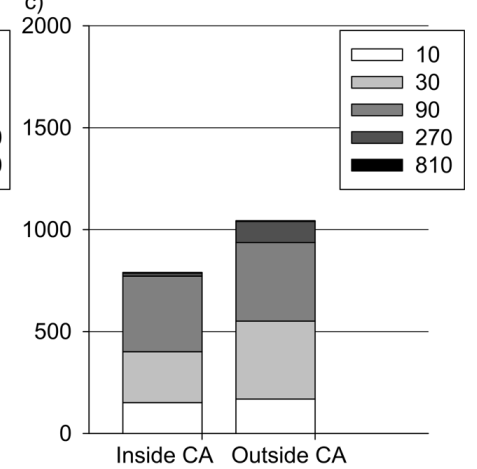

Fig. 5. Suggested intensity levels for tourism and recreation infrastructure in the study area based on total ecological score (TES). TES $=0$ : suitable for heavy construction; TES 10-80: suitable for intermediate construction; TES 90-800, suitable for light infrastructure; TES $\geq 810$, unsuitable for tourism or recreation.

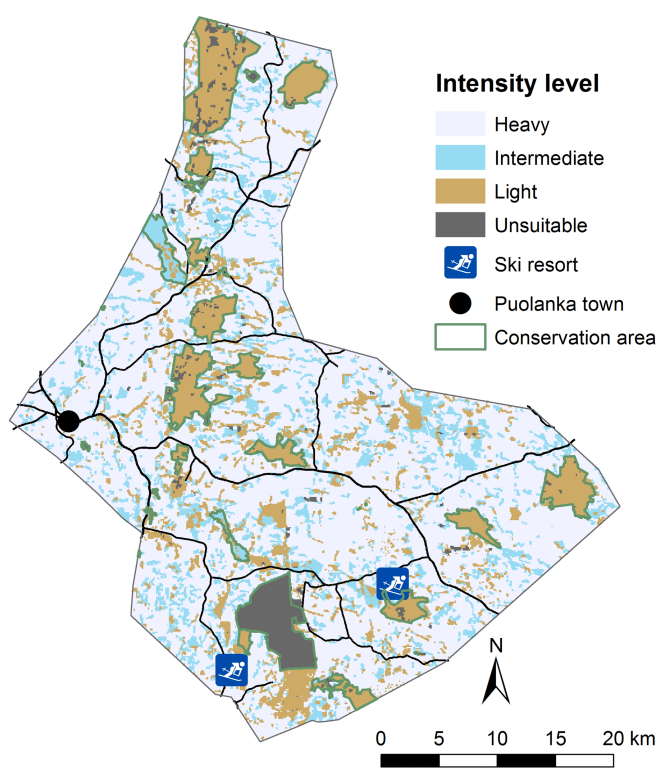

considered equally valuable layers, because they highlighted ecologically valuable areas both within and outside of nature conservation areas. Thus, they can be used to evaluate the success of nature conservation. The MODELING layer was given less weight than the other layers by limiting the maximum layer score to 90 . The reason for this is that the MODELING layer was based on estimated values, whereas the other layers were based on verified observations of habitats or species. We used all available ecological data sets in this study, and they have not been assessed simultaneously before. However, the use of all possible data sets may not be cost-effective, and focusing on key data that indicate the majority of the aspects of biodiversity may be more feasible. What the key data are, and in which situation, needs to be addressed first.

The RESTRICTED layer contributed most to TES. Because valuable habitats and species have been the key reason for conserving these areas, it also indicates that detailed biodiversity inventories have focused specifically on these areas. Consequently, the RESTRICTED layer was biased by default. Despite its limitations, the usability of this layer is high, because most data are easily available and directly applicable.

Habitat-level data are generally essential for assessing environments with high biodiversity in the landscape. The HABITAT layer had high coverage in the study area and made a high contribution to TES. The layer also provided information on ecologically valuable areas outside the RESTRICTED layer areas. This is important for planning that is particularly targeted 
outside conservation or other restricted areas. The drawback of the layer was that the information on threatened habitats was limited to state-owned land. There were also difficulties in locating the threatened habitats accurately, because the attributes had to be derived manually from proxy information. The classification of threatened habitats is quite recent in Finland (Raunio et al. 2008), and the coverage of the data is still limited. However, along with increasing inventories, the usability of the habitat data will increase.

The SPECIES layer provided information from both within and outside of the restricted areas, but the overall importance of the SPECIES layer was low because of the low areal coverage. Essential limitations were also that the data were only available for research purposes and had not been systematically collected. The lack of comprehensive spatial data on species is a common problem (Vihervaara et al. 2015). One option to overcome this constraint is habitat suitability modeling, which is increasingly used to locate potential habitats of threatened or rare species (e.g., López- López et al. 2007, Aizpura et al. 2015). In this study, the MODELING layer had the largest coverage over the study area, and it showed a relatively low correlation with the RESTRICTED layer. This indicates a high complementarity of these two layers. However, the main limitations of the MODELING layer are that the modeling also uses species data, which is not yet publicly available; it requires expert knowledge, which is not always available in practical land use planning; and that the habitat suitability models are always subject to a certain level of uncertainty (Barry and Elith 2006, Aizpurua et al. 2015). Nevertheless, the modeling approach creates a promising opportunity for scientific research to be integrated into land use planning, as has already taken place in two examples using the present approach (Kangas et al. 2013, Tolvanen et al. 2014). Once the modeling and data use procedures are made operational, they can be applied routinely, which increases the cost-effectiveness (e.g., Aizpura et al. 2015), the importance, and the usability of the modeling considerably.

\section{Applicability of the method in land use planning}

Several approaches based on spatial data have been used to assess the ecological value of landscape features (e.g., Margules and Pressey 2000, Theobald and Hobbs 2002, Willis et al. 2012, Kareksela et al. 2013) and ecosystem services (Maes et al. 2011, 2012, Vihervaara et al. 2012). Rather than aiming at prioritizing and identifying optimal targets for a certain land use type (e.g., Kareksela et al. 2013, Lehtomäki and Moilanen 2013), our aim was to provide a flexible method that can be used to provide baseline information on ecological values in practically any type of land use planning. For example, the method can serve as a preplanning tool for further analyses, such as an Environmental Impact Assessment, which benefits from the detailed information on the potential location of valuable species and habitats (Willis et al. 2012). Field inventories can thereafter be focused on these areas, which increases the cost-effectiveness of the planning procedure.

We demonstrated our method by evaluating the success of nature conservation and by addressing ecologically sustainable areas for tourism and recreational infrastructure within the study area. Quantitative evaluation on how conservation targets have been achieved is an important part of conservation planning (Margules and Pressey 2000). The establishment of conservation areas may be based partially on their aesthetics and low economic value (e.g.,
Pressey 1994, Margules and Pressey 2000, Scott et al. 2001, Polasky et al. 2005), which emphasizes the importance of addressing biodiversity and conservation values both within and outside existing nature conservation areas. In our study, most of the cells with a high TES were located in existing nature conservation areas, which indicates that the current nature conservation area network quite successfully identifies ecologically valuable areas. Nevertheless, this is partially a result of the bias in the scoring of conservation areas, because they achieve a high TES from their conservation status per se, and because the habitats and species have been inventoried more systematically within than outside conservation areas. A considerable number of ecologically valuable areas were also located outside the conservation areas. The areas with high ecological value (TES $\geq 810$ ) should be the subject of special concern, because they contain critically endangered habitats or species. Also, areas with lower ecological values are important, because they can be used directly or restored for increasing the connectivity between the conservation areas and to provide multiple ecosystem services.

In our demonstration that considered ecologically sustainable tourism and recreational planning, tourism infrastructure and the safeguarding of biodiversity were permitted to coexist in most areas. The exception was the areas with the highest TES, i.e., the strict nature reserve and areas with critically endangered habitats or species. This approach is similar to zoning, which is used in nature conservation areas to restrict the recreational use of the most sensitive areas (e.g., Eagles et al. 2002). Our method expands the method outside conservation areas. Expanding the focus from nature conservation to the safeguarding of biodiversity at the landscape level requires the simultaneous consideration of ecological values and socioeconomic needs (Polasky et al. 2005, Rossi et al. 2008). Linking ecosystem services such as tourism and recreation to ecological values is important when trade-offs between nature conservation and economic returns are evaluated. Our method can be expanded to include stakeholder perspectives in the spatial model, which provides an opportunity to pinpoint areas with overlapping land use interests (A. Tolvanen et al. 2014).

\section{CONCLUSIONS}

We provide a new approach to using multiple data sets for sustainable land use planning. We were able to overcome the three main constraints that limit the use of ecological data in land use planning: poor availability of spatial data, limited accessibility of spatial data, and the need for a high level of expertise to utilize and analyze the data. However, this does not indicate that the method is directly applicable to all stakeholders involved in land use planning. The availability of ecological data is still limited and seems to be concentrated in well-surveyed nature conservation areas, in which competing land use pressures are low. Many data sets, especially the data from private land and on threatened species, are still limited to research purposes. Habitat modeling still requires expertise. All these constraints mean that a considerable amount of land use planning is still carried out without important existing information on the target area. As increasing data become available and open access, and modeling tools improve, the usability and applicability of the method will increase. The method can be transferred to other regions or countries provided that the scoring is adapted to local conditions and available data sets. The method can also be further developed 
to include variables related to social and economic sustainability, infrastructure, and also ecosystem services other than tourism and recreation.

Responses to this article can be read online at: http://www.ecologyandsociety.org/issues/responses. $\mathrm{php} / 8590$

\section{Acknowledgments:}

We acknowledge all organizations and actors that provided data for the study: Centre for Economic Development, Transport and the Environment (Kainuu Ely), Metsähallitus, Finnish Forest Centre, Finland's environmental administration, Kainuu regional ornithological society, and the Finnish Museum of Natural History. We thank Ari Räjäsärkkä and Panu Keihäs from Metsähallitus and Antti Nousiainen for their help with the data and ecological scoring. This work was financially supported by the Finnish Forest Research Institute, Natural Resources Institute Finland, University of Oulu, the European Regional Development Fund project "Socioecological tools for the planning of tourist destinations in Kainuu VAAKA," and project 283153 funded by the Academy of Finland.

\section{LITERATURE CITED}

Aizpurua, O., L. Cantú-Salazar, G. San Martin, G. Biver, L. Brotons, and N. Titeux. 2015. Reconciling expert judgement and habitat suitability models as tools for guiding sampling of threatened species. Journal of Applied Ecology 52(6):1608-1616. http://dx.doi.org/10.1111/1365-2664.12515

Ballantyne, M., and C. M. Pickering. 2013. Tourism and recreation: a common threat to IUCN red-listed vascular plants in Europe. Biodiversity and Conservation 22:3027-3044. http://dx. doi.org/10.1007/s10531-013-0569-2

Balmford, A., J. Beresford, J. Green, R. Naidoo, M. Walpole, and A. Manica. 2009. A global perspective on trends in nature-based tourism. PLoS Biology 7(6):e1000144. http://dx.doi.org/10.1371/ journal.pbio. 1000144

Balmford, A., J. M. H. Green, M. Anderson, J. Beresford, C. Huang, R. Naidoo, M. Walpole, and A. Manica. 2015. Walk on the wild side: estimating the global magnitude of visits to protected areas. PLoS Biology 13(2):e1002074. http://dx.doi. org/10.1371/journal.pbio.1002074

Barry, S., and J. Elith. 2006. Error and uncertainty in habitat models. Journal of Applied Ecology 43(3):413-423. http://dx.doi. org/10.1111/j.1365-2664.2006.01136.X

Burnham, K. P., and D. R. Anderson. 2002. Model selection and multi-model inference: a practical information-theoretic approach. Second edition. Springer-Verlag, New York, New York, USA.

Butchart S. H. M., M. Walpole, B. Collen, A. van Strien, J. P. W. Scharlemann, R. E. A. Almond, J. E. M. Baillie, B. Bomhard, C. Brown, J. Bruno, K. E. Carpenter, G. M. Carr, J. Chanson, A. M. Chenery, J. Csirke, N. C. Davidson, F. Dentener, M. Foster, A. Galli, J. N. Galloway, P. Genovesi, R. D. Gregory, M. Hockings, V. Kapos, J-F. Lamarque, F. Leverington, J. Loh, M. A. McGeoch,
L. McRae, A. Minasyan, M. Hernández Morcillo, T. E. E. Oldfield, D. Pauly, S. Quader, C. Revenga, J. R. Sauer, B. Skolnik, D. Spear, D. Stanwell-Smith, S. N. Stuart, A. Symes, M. Tierney, T. D. Tyrrell, J-C. Vié, and R. Watson. 2010. Global biodiversity: indicators of recent declines. Science 328:1164-1168. http://dx. doi.org/10.1126/science.1187512

Cole, D. N., and P. B. Landres. 1996. Threats to wilderness ecosystems: impacts and research needs. Ecological Applications 6:168-184. http://dx.doi.org/10.2307/2269562

Eagles, P.F.J., S.F. McCool, and C.D. Haynes. 2002. Sustainable tourism in protected areas: guidelines for planning and management. IUCN Gland, Switzerland, and Cambridge, UK.

Environmental Systems Research Institute (ESRI). 2011. ArcGIS Desktop, Release 10. ESRI, Redlands, California, USA.

Hosmer D. W., Jr., anad S. Lemeshown. 2000. Applied logistic regression. Second edition. Wiley, New York, New York, USA.

Järvinen, O., and R. A. Väisänen. 1975. Estimating relative densities of breeding birds by line transect method. Oikos 26:316-322. http://dx.doi.org/10.2307/3543502

Kangas, K., A. Tolvanen, T. Kälkäjä, and P. Siikamäki. 2009. Ecological impacts of revegetation and management practices of ski slopes in Northern Finland. Environmental Management 44 (3):408-419. http://dx.doi.org/10.1007/s00267-009-9336-2

Kangas, K., A. Tolvanen, M. Keränen, and J. Moilanen. 2013. Oulun luonnon monimuotoisuus, VILMO_Viheralueverkosto ja luonnon monimuotoisuus [in Finnish]. Finnish Forest Research Institute and the City of Oulu, Finland. [online] URL: http:// www.ouka.fi/c/document library/get file?uuid $=69340961$ aa5f-44ea-82c4-9e22a26eaacb\&groupId $=64220$

Kareksela, S., A. Moilanen, S. Tuominen, and J. S. Kotiaho. 2013. Use of inverse spatial conservation prioritization to avoid biological diversity loss outside protected areas. Conservation Biology 27(6):1294-1303. http://dx.doi.org/10.1111/cobi.12146

Krueger, T., T. Page, K. Hubacek, L. Smith, and K. Hiscock 2012. The role of expert opinion in environmental modelling. Environmental Modelling \& Software 36:4-18. http://dx.doi. org/10.1016/j.envsoft.2012.01.011

Laine, A. M., M. Leppälä, O. Tarvainen, M.-L. Päätalo, R. Seppänen, and A. Tolvanen. 2011. Restoration of managed pine fens: effect on hydrology and vegetation. Applied Vegetation 14 (3):340-349. http://dx.doi.org/10.1111/j.1654-109X.2011.01123. $\underline{\mathrm{X}}$

Laniak, G. F., G. Olchin, J. Goodall, A. Voinov, M. Hill, P. Glynn, G. Whelan, G. Geller, N. Quinn, M. Blind, S. Peckham, S. Reaney, N. Gaber, R. Kennedy, and A. Hughes. 2013. Integrated environmental modeling: a vision and roadmap for the future. Environmental Modelling \& Software 39:3-23. http://dx.doi. org/10.1016/j.envsoft.2012.09.006

Lehtomäki, J., and A. Moilanen. 2013. Methods and workflow for spatial conservation prioritization using Zonation. Environmental Modelling \& Software 47:128-137. http://dx.doi. org/10.1016/j.envsoft.2013.05.001 
López-López, P., C. Garcia-Ripolles, A. Soutullo, L. Cadahia, and V. Urios. 2007. Identifying potentially suitable nesting habitat for golden eagles applied to 'important bird areas' design. Animal Conservation 10:208-218. http://dx.doi.org/10.1111/

j.1469-1795.2006.00089.x

Infrastructure for Spatial Information in the European Community (INSPIRE). 2007. INSPIRE EU Directive. Directive 2007/2/EC of the European Parliament and of the Council of 14 March 2007 establishing an Infrastructure for Spatial Information in the European Community (INSPIRE). Official Journal of the European Union L 108/1, Volume 50, 25 April 2007. [online] URL: http://eur-lex.europa.eu/JOHtml.do?uri=OJ:L:2007:108: SOM:EN:HTML:

Maes, J., L. Braat, K. Jax, M. Hutchins, E. Furman, M. Termansen, S. Lucque, M. L. Paracchini, C. Chauvin, R. Williams, M. Volk, S. Lautenbach, L. Kopperoinen, M.-J. Schelhaas, , J. Weinert, , M. Goossen, E. Dumont, M. Strauch, C. Görg, C. Dormann, M. Katwinkel, G. Zulian, R. Varjopuro, J. Hauck, M. Forsius, G. Hengeveld, , M. Perez-Soba, F. Bouraoui, M. Scholz, C. Schilz-Zunkel, A. Lepisto, Y. Polishchuk, G. Bidoglio. 2011. A spatial assessment of ecosystem services in Europe: methods, case studies and policy analysisphase 1. PEER Report No 3. Ispra: Partnership for European Environmental Research.

Maes, J., M. L. Paracchini, G. Zulian, M. B. Dunbar, and R. Alkemade. 2012. Synergies and trade-offs between ecosystem service supply, biodiversity, and habitat conservation status in Europe. Biological Conservation 155:1-12. http://dx.doi. org/10.1016/j.biocon.2012.06.016

Margules, C. R., and R. L. Pressey. 2000. Systematic conservation planning. Nature 405:243-253. http://dx.doi.org/10.1038/35012251

McGarigal, K., and B. J. Marks. 1995. Fragstats: spatial pattern analysis program for quantifying landscape structure. General Technical Report PNW-GTR-351. U.S. Department of Agriculture, Forest Service, Pacific Northwest Research Station, Portland, Oregon, USA.

Millennium Ecosystem Assessment. 2005 Ecosystems and human well-being: synthesis. Island Press, Washington, D.C., USA.

Moilanen, A., A. M. A. Franco, R. I. Early, R. Fox, B. Wintle, and C. D. Thomas. 2005. Prioritizing multiple-use landscapes for conservation: methods for large multispecies planning problems. Proceedings of Royal Society B: Biological Sciences 272:1885-1891. http://dx.doi.org/10.1098/rspb.2005.3164

Naidoo, R., L. C. Weaver, G. Stuart-Hill, and J. Tagg. 2011. Effect of biodiversity on economic benefits from communal lands in Namibia. Journal of Applied Ecology 48(2):310-316. http://dx.doi. org/10.1111/j.1365-2664.2010.01955.X

Polasky S., E. Nelson, E. Lonsdorf, P. Fackler, and A. Starfield. 2005. Conserving species in a working landscape: land use with biological and economic objectives. Ecological Applications 15:1387-401. http://dx.doi.org/10.1890/03-5423

Pressey, R. L. 1994. Ad hoc reservations: forward or backward steps in developing representative reserve systems? Conservation Biology 8(3):662-668. http://dx.doi.org/10.1046/j.1523-1739.1994.08030662.
Puhakka, R. 2007. National parks in transition. A study of the iteraction between nature conservation and tourism [in Finnish with English summary]. Publications on Social Sciences No. 81. University of Joensuu, Joensuu, Finland.

Rajasärkkä, A. 2004. Kainuun ja Vienan Karjalan metsä-ja suolinnustot sekä niiden merkitys luontomatkailun kannalta [in Finnish]. Alueelliset ympäristöjulkaisut 347:47-126.

Rassi, P, E. Hyvärinen, A. Juslén, and I. Mannerkoski, editors. 2010. The 2010 red list of Finnish species [in Finnish with English summary]. Ministry of the Environment and Finnish Environment Institute, Helsinki, Finland.

Raunio, A., A. Schulman, and T. Kontula, editors. 2008. Assessment of threatened habitat types in Finland-Finnish Environment Institute (SYKE), Helsinki. The Finnish Environment 8/2008. Parts 1 and 2. Finnish Environment Institute, Helsinki, Finland.

Rossi, P., A. Pecci, V. Amadio, R. Orazio, and L. Soliani. 2008. Coupling indicators of ecological sensitivity with indicators of demographic pressure in the demarcation of new areas to be protected: the case of the Oltrepo Pavese and Ligurian-Emilian Apennine area (Italy). Landscape and Urban Planning 85 (1):12-26. http://dx.doi.org/10.1016/j.landurbplan.2007.09.002

Rytteri, T., and R. Puhakka. 2012. The art of neoliberalizing park management: commodification, politics and hotel construction in Pallas-Yllästunturi National Park, Finland. Geografiska Annaler: Series B, Human Geography 94(3):255-268. http://dx.doi. org/10.1111/j.1468-0467.2012.00413.x

Saarinen, J. 2003. The regional economics of tourism in Northern Finland: the socioeconomic implications of recent tourism development and future possibilities for regional development. Scandinavian Journal of Hospitality and Tourism 3(2):91-113. http://dx.doi.org/10.1080/15022250310001927

Saarinen, J. 2005. Tourism in the Northern wildernesses: wilderness discourses and the development of nature-based tourism in northern Finland. Pages 36-49 in C. M. Hall and S. Boyd, editors. Nature-based tourism in peripheral areas. Development or disaster. Channel View Publications, Clevedon, UK.

Sarkar, S., R. L. Pressey, D. P. Faith, C. R. Margules, T. Fuller, D. M. Stoms, A. Moffett, K. A. Wilson, K. J. Williams, P. H. Williams, and S. Andelman. 2006. Biodiversity conservation planning tools: present status and challenges for the future. Annual Review of Environment and Resources 31:123-159. http:// dx.doi.org/10.1146/annurev.energy.31.042606.085844

SAS Institute. 2004. SAS 9.1.3 help and documentation. SAS Institute, Cary, North Carolina, USA.

Scott J. M., F. W. Davis, R. G. McGhie, R. G. Wright, C. Groves, and J. Estes. 2001. Nature reserves: do they capture the full range of America's biological diversity? Ecological Applications 11:999-1007. http://dx.doi.org/10.1890/1051-0761(2001)011[0999: NRDTCT]2.0.CO;2

Theobald, D. M., and N. T. Hobbs. 2002. A framework for evaluating land use planning alternatives: protecting biodiversity on private land. Conservation Ecology 6(1):5. [online] URL: $\underline{\text { http:// }}$ www.consecol.org/vol6/iss1/art. 
Tolvanen, A., and K. Kangas. 2016. Tourism, biodiversity and protected areas - review from northern Fennoscandia. Journal of Environmental Management. 169:58-66. http://dx.doi.org/10.1016/ j.jenvman.2015.12.011

Tolvanen, A., K. Kangas, I. Vendelin, E. Huhta, M. Hytönen, A. Jäkäläniemi, M. Kyttä, A. Nikula, V. Nivala, O. Tarvainen, S. Tuulentie, and L. Tyrväinen. 2014. Vaaka punnitsee, arvottaa, tasapainottaa-toimintamalli Vaara-Kainuun matkailualueiden suunnitteluun [in Finnish]. Finnish Forest Research Institute, Oulu, Finland.[online] URL: http://www.metla.fi/julkaisut/ isbn/978-951-40-2483-2/vaaka-raportti.pdf

Tomppo, E., M. Haakana, M. Katila, and J. Peräsaari. 2008. Multi-source national forest inventory methods and applications. Managing Forest Ecosystems Series. Springer, New York, New York, USA.

Turner, W., C. Rondinini, N. Pettorelli, B. Mora, A. K. Leidner, Z. Szantoi, G. Buchanan, S. Dech, J. Dwyer, M. Herold, L. P. Koh, P. Leimgruber, H. Taubenboeck, M. Wegmann, M. Wikelskim, and C. Woodcock. 2015. Free and open-access satellite data are key to biodiversity conservation. Biological Conservation 182:173-176. http://dx.doi.org/10.1016/j.biocon.2014.11.048

Väisänen, R. A., E. Lammi, and P. Koskimies. 1998. Distribution, numbers and population changes of Finnish breeding birds [in Finnish with English summary]. Otava, Helsinki, Finland.

Vihervaara, P., T. Kumpula, A. Ruokolainen, A. Tanskanen, and B. Burkhard. 2012. The use of detailed biotope data for linking biodiversity with ecosystem services in Finland. International Journal of Biodiversity Science, Ecosystem Services \& Management 8(1-2):169-185. http://dx.doi.org/10.1080/2151373$\underline{2.2012 .686120}$

Vihervaara, P., L. Mononen, A.-P. Auvinen, R. Virkkala, Y. Lü, I. Pippuri, P. Packalen, R. Valbuena, and J. Valkama., 2015. How to integrate remotely sensed data and biodiversity for ecosystem assessment at landscape scale. Landscape Ecology 30(3):501-516. http://dx.doi.org/10.1007/s10980-014-0137-5

Willis, K. J., E. S. Jeffers, C. Tovar, P. R. Long, N. Caithness, M. G. D. Smit, R. Hagemann, C. Collin-Hansen, and J. Weissenberger. 2012. Determining the ecological value of landscapes beyond protected areas. Biological Conservation 147:3-12. http://dx.doi.org/10.1016/j.biocon.2011.11.001

Wipf, S., C. Rixen, M. Fischer, B. Schmid, and V. Stoeckli. 2005. Effects of ski piste preparation on alpine vegetation. Journal of Applied Ecology 42:306-316. http://dx.doi.org/10.1111/ j.1365-2664.2005.01011.x

Woodcock, C. E., R. Allen, M. Anderson, A. Belward, , R. Bindschadler, W. Cohen, B., F. Gao, S. N. Goward, D. Helder, E. Helmer, R. Nemani, L. Oreopoulos, J. Schott, P. S. Thenkabail, E. F. Vermote, J. Vogelmann, M. A. Wulder, and R. Wynne. 2008. Free access to Landsat imagery. Science 320:1011. http://dx.doi. org/10.1126/science.320.5879.1011a

Wulder, M. A., J. G. Masek, W. B. Cohen, T. R. Loveland, and C. E. Woodcock. 2012. Opening the archive: how free data has enabled the science and monitoring promise of Landsat. Remote Sensing of Environment 122:2-10. http://dx.doi.org/10.1016/j. rse.2012.01.010 